\section{Spermidine Facilitates PCR Amplification of Target DNA}

\section{Ching-Yi Wan and Thea A. Wilkins}

Department of Agronomy and Range Science, University of California, Davis, California 95616-8515
Recent advances in PCR have made this technique one of the most powerful tools for a wide spectrum of molecular analyses, such as genome mapping, molecular evolution, diagnosis of genetic disease, and forensic sciences. ${ }^{(1)}$ Many PCR applications involve the specific and reproducible amplification of genomic DNA from biological samples. However, inconsistent PCR amplification results are linked primarily to the quality and quantity of the template, as well as other parameters, such as components in the reaction mixture, cycling conditions, and the type of thermal cycler used. Genomic DNA isolated from plants is known to contain higher levels of phenolic compounds and polysaccharides than DNA purified from animal cells. Phenolic compounds are especially troublesome because they oxidize readily during homogenization, irreversibly interact with proteins and nucleic acids and, consequently, hinder molecular analysis. ${ }^{(2)}$ Inclusion of adjuvants such as DMSO and Tween 20 are reported to counteract the inhibitory effects on PCR by some plant acidic polysaccharides. ${ }^{(3)}$ Under conditions where the nucleotide composition or the quality of DNA is a limiting factor, techniques such as "hotstart" PCR, $(1,4,5)$ "GC clamp," (1) the addition of single-stranded DNA-binding protein, ${ }^{(6)}$ or formamide ${ }^{(7)}$ to the reaction mixture have been found to improve the specificity of amplification from genomic DNA.

Spermidine [N-(3-aminopropyl)-1,4butanediamine] is a polyamine that is routinely included in restriction enzyme digestions to improve the cleavage efficacy of the DNA. Spermidine counteracts the inhibitory effects of contaminants coisolated with DNA and consequently permits complete digestion of the DNA at lower enzyme concentrations. Experiments in vitro show that spermidine has a high affinity for nucleic acids and neutralizes at least part of the negative charges in the phosphate backbone, thereby stabilizing DNA and RNA. ${ }^{(8)}$ Polyamines are also known to stimulate the activities of the enzymes involved in nucleic acid metabolism, such as DNA and RNA polymerases ${ }^{(9,10)}$ and topoisomerases. ${ }^{(11)}$ In this paper we examined the stimulating effect of spermidine and several PCR enhancers on amplification of the $69-\mathrm{kD}$ vacuolar $\mathrm{H}^{+}$-ATPase catalytic subunit (subunit A) genes from cotton genomic DNA. Contrary to earlier re- ports spurning the use of polyamines in PCR, ${ }^{(12)}$ we determined that micromolar concentrations of spermidine enhanced PCR amplification significantly from plant DNA and that inclusion of spermidine to reactions was vastly superior to the compensatory effects of hotstart PCR. Reactions supplemented with the PCR adjuvants dimethylsulfoxide (DMSO), formamide, or Tween 20 failed to amplify target genes, suggesting that acidic polysaccharides were not a contributing factor to PCR amplification problems encountered with the DNA used in this study.

\section{MATERIALS AND METHODS Cotton Genomic DNA Isolation}

Young expanding cotton leaves were harvested from diploid (Gossypium herbaceum L. and G. laxum Phillips, genome designation $A_{1}$ and $D_{8}$, respectively) and tetraploid [G. hirsutum L., genome designation $(\mathrm{AD})_{1}$ ] plants grown in the greenhouse. The leaves were frozen in liquid nitrogen and stored at $-80^{\circ} \mathrm{C}$ until use. Genomic DNA was isolated according to the procedures described by Galau et al. ${ }^{(13)}$ except for the following modifications. The extraction buffer contained $0.5 \%$ sodium deoxycholate (wt/vol), and $0.5 \% \mathrm{NP}-40$ (vol/vol), and $20 \mathrm{~mm}$ dithiothreitol (DTT), which was substituted for 2-mercaptoethanol. Nucleic acid pellets recovered after isopropanol precipitation were washed gently with $70 \%$ ethanol, lyophilized, and resuspended in $\mathbf{1 . 5}$ $\mathrm{ml}$ of TE buffer $[10 \mathrm{~mm}$ Tris- $\mathrm{HCl}(\mathrm{pH}$ 8.0), $1 \mathrm{~mm}$ EDTA]. The resuspended genomic DNA was purified further by $\mathrm{CsCl}$ density gradient centrifugation as described by Maniatis et al. ${ }^{(14)}$ For non$\mathrm{CsCl}$ purified DNA, the nucleic acid pellet was resuspended in TE buffer containing RNase A at a concentration of 1.0 $\mathrm{mg} / \mathrm{ml}$ and incubated overnight at $4^{\circ} \mathrm{C}$. Proteinase K (U.S. Biochemical 20818) was added to the DNA to a final concentration of $50 \mu \mathrm{g} / \mathrm{ml}$ of TE buffer and incubated at $42^{\circ} \mathrm{C}$ for $1.5 \mathrm{hr}$. The genomic DNA was extracted once with phenol/ chloroform/isoamyl alcohol (25:24:1, $\mathrm{vol} / \mathrm{vol} / \mathrm{vol}$ ), followed by another extraction with chloroform/isoamyl alcohol $(24: 1, \mathrm{vol} / \mathrm{vol})$. The size of the genomic DNA was estimated by agarose gel electrophoresis, and DNA concentrations were determined in a DNA fluorometer or spectrophotometer. 


\section{PCR Amplification of Genomic DNA}

Two synthetic oligonucleotide primers (COT2 and COT8) were used to amplify the nonhomologous region of the $69-\mathrm{kD}$ vacuolar $\mathrm{H}^{+}-$ATPase subunit genes from cotton. ${ }^{(15)}$ The PCR reactions contained the following components unless specified: $20 \mathrm{ng}$ of genomic DNA per $25-\mu \mathrm{l}$ reaction and $0.2 \mu \mathrm{M}$ of each primer, 50 $\mathrm{mm} \mathrm{KCl}, 10 \mathrm{~mm}$ Tris- $\mathrm{HCl}(\mathrm{pH} 8.8$ at $25^{\circ} \mathrm{C}$ ), $1.5 \mathrm{~mm} \mathrm{MgCl}_{2}, 0.1 \%$ (vol/vol) Triton X-100, $50 \mu \mathrm{M}$ of each dNTP, and 0.04 units of Taq DNA polymerase (Promega) per microliter of reaction. PCR mixtures were supplemented with 5\% DMSO (vol/ vol), $5 \%$ formamide ( $\mathrm{vol} / \mathrm{vol}$ ), $0.5 \%$ Tween $20(\mathrm{vol} / \mathrm{vol}),{ }^{(3)}$ or $0.1-2$ mm spermidine. The reaction mixture was overlayed with an equal volume of mineral oil and submitted to denaturation for 2 min at $94^{\circ} \mathrm{C}$ in a Ericomp thermal cycler, followed by 30 cycles of amplification (1 min at $94^{\circ} \mathrm{C}, 1 \mathrm{~min}$ at $48^{\circ} \mathrm{C}$, and $1 \mathrm{~min}$ at $72^{\circ} \mathrm{C}$ ) and an elongation cycle of $10 \mathrm{~min}$ at $72^{\circ} \mathrm{C}$. Hot-start PCR was performed by adding the Taq polymerase at $80^{\circ} \mathrm{C}$ after denaturation for $2 \mathrm{~min}$ at $94^{\circ} \mathrm{C}$, followed by PCR amplification with regular cycling conditions. The products were analyzed by agarose gel electrophoresis and visualized under UV light.

\section{RESULTS AND DISCUSSION}

Extraction of high-quality genomic DNA for molecular analysis from most plant species frequently requires tedious purification procedures. Gossypium (cotton) species are especially recalcitrant because of interference by elevated levels of endogenous polysaccharides and phenolic compounds. PCR amplification of genomic DNA isolated by different methods or on different dates was highly variable because of the quality of the template DNA. However, purity does not necessarily explain the occasional inconsistency observed in PCR amplification of CsCl-purified genomic DNA from the same preparation. Spermidine is known to enhance the ability of restriction enzymes to digest "dirty" $\mathrm{DNA}^{(8)}$ and stimulate the enzyme activities of DNA and RNA polymerases in vitro. ${ }^{(9)}$ Therefore, our goal was to examine the influence of spermidine and several other PCR enhancers on amplification of DNA from various sources by Taq DNA polymerase.

To investigate the effect of spermidine in PCR, vacuolar $\mathrm{H}^{+}$-ATPase sub- unit A genes were amplified from non$\mathrm{CsCl}$ - and CsCl-purified genomic DNA isolated from three cotton species. Two genomic PCR fragments of 558 and 690 bp were expected to be amplified by the selected primers as shown in Figure 1. The amplification reactions with nonCsCl-purified DNA were either unsuccessful (lane 5) or produced a low yield of only the 558-bp fragment (lanes 1,3). CsCl-purified DNA greatly improved the PCR amplification of both fragments; however, variability in yield of the 690bp fragment was observed from experiment to experiment (lanes 7,8). Supplementing the reactions with $1 \mathrm{~mm}$ spermidine significantly enhanced the amplification of both genomic fragments from either non- $\mathrm{CsCl}$ - or $\mathrm{CsCl}$ purified templates (lanes 2,4,6,9). A titration of spermidine concentrations spanning from 0.1 to $2 \mathrm{~mm}$ established an optimal range between 0.2 and $1 \mathrm{~mm}$ (data not shown).

Alternative approaches, such as hotstart PCR, have been developed to improve specificity of PCR amplification. Hot-start PCR is reported to minimize nontarget amplification and the formation of primer-dimer. ${ }^{(1)}$ The enhancing effects of hot start versus spermidine in PCR amplification from non-CsCl-purified cotton genomic DNA was investigated. As shown in Figure 2, amplification of non-CsCl-purified DNA with PCR was either unsuccessful (lane 1) or produced low yields of only the 558-bp fragment (lane 2). Slight enhancement of PCR amplification by hot start was ob-

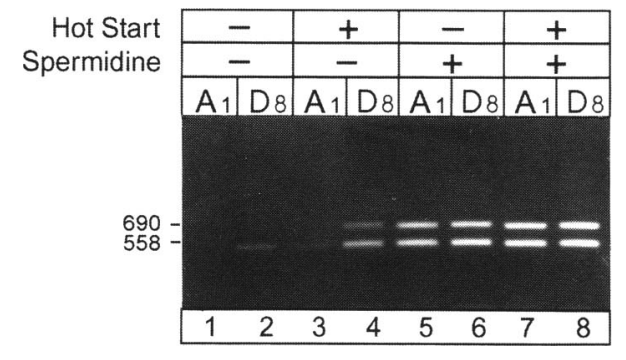

FIGURE 1 The effect of $1 \mathrm{~mm}$ spermidine in PCR amplification of the nonhomologous region of vacuolar $\mathrm{H}^{+}$-ATPase subunit $\mathrm{A}$ genes from non-CsCl-purified (lanes 1-6) and $\mathrm{CsCl}$ purified (lanes 7-9) cotton genomic DNA from three Gossypium species [genome designations $A_{1}, D_{8}$, and $\left.(A D)_{1}\right]$. Significant enhancement in yields of the expected 558- and 690-bp fragments by spermidine (lanes $2,4,6,9$ ) was observed compared with reactions without spermidine (lanes 1,3,5,7).

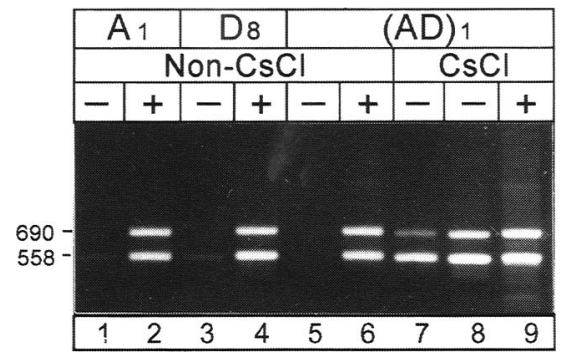

FIGURE 2 Comparison of the enhancing effect of hot-start PCR and spermidine. Slight enhancement of PCR amplification by hotstart PCR (lanes 3,4) relative to conventional PCR (lanes 1,2) was observed. Addition of spermidine alone (lanes 5,6) and combination of hot start plus spermidine (lanes 7,8 ) showed significant improvement in yield of both 558- and 690-bp fragments of the vacuolar $\mathrm{H}^{+}$-ATPase subunit A genes from cotton.

served by the increased yield of the 558bp fragment (lane 3 ) and the presence of the 690-bp fragment (lane 4). However, hot-start PCR was often ineffectual in enhancing PCR amplification, or the results were highly variable (data not shown). The efficacy of using hot-start PCR was presumably influenced by the timing and degree of mechanical mixing of the enzyme in the reaction. However, the supplement of $0.4 \mathrm{~mm}$ spermidine to the reactions significantly enhanced the amplification of both fragments (lanes 5,6). The combination of hot-start PCR and spermidine produced results similar to those with the addition of spermidine alone (lanes 5,6), indicating that spermidine was superior in ameliorating PCR specificity, especially when dirty DNA was employed as a template. No potential synergistic effects were observed in any hot-start PCR amplification experiments supplemented with spermidine. Relative to hot-start PCR, the initial addition of spermidine to reaction mixtures simplifies PCR amplification setup procedures.

Optimization of PCR amplification conditions by the addition of common laboratory reagents has gained widespread attention. Inclusion of formamide as a denaturant increases the specificity during PCR amplification of genomic DNA, especially GC-rich regions. ${ }^{(7)}$ In particular, DMSO and Tween 20 counteract the inhibitory effects of some acidic polysaccharides on PCR amplification of plant DNA, whereas formamide is ineffectual. ${ }^{(3)}$ However, despite the promise of these buffer adjuvants as 
PCR enhancers, reactions supplemented with DMSO, formamide, or Tween 20 failed to produce the expected PCR products in our laboratory (data not shown), indicating that polysaccharides were not a consideration.

Spermidine enhancement of PCR was consistent and reproducible in independent experiments using assorted primer pairs and different sources of DNA. For instance, vacuolar $\mathrm{H}^{+}$-ATPase subunit $\mathrm{A}$ genes from other plant species were not evident following PCR amplification in the absence of spermidine, whereas the expected PCR products were amplified successfully in the presence of spermidine as detected by DNA hybridization (data not shown). Thus, the increased quality, yield, and specificity of PCR products generated in a broad spectrum of applications in our laboratory indicate that the routine supplement of spermidine to the PCR reactions apparently compensates for contaminants in DNA that tend to inhibit PCR amplification. The enhancing effect of spermidine was also observed on PCR amplification of phage DNA, phage libraries, plasmid DNA, cDNAs, and DNA in low-meltingpoint agarose (data not shown).

Spermidine is an inexpensive chemical that exerts a significant enhancing effect in PCR amplification of DNA with higher specificity and reproducibility, yet allows simplified DNA isolation and PCR reaction setup procedures to be employed. The addition of spermidine in the PCR amplification reactions may also be advantageous in random amplified polymorphic DNA-PCR (RAPDPCR), as well as other general PCR applications and genetic analysis.

\section{ACKNOWLEDGMENTS}

This work was supported by grants from the U.S. Department of Energy (DEFG03-92ER20067) and Cotton Incorporated to T.A.W.

\section{REFERENCES}

1. Erlich, H.A., D. Gelfand, and J.J. Sninsky. 1991. Recent advances in the polymerase chain reaction. Science 252: 1643-1651.

2. Loomis, W.D. 1974. Overcoming problems of phenolics and quinones in the isolation of plant enzymes and organelles. Methods Enzymol. 31: 528-545.

3. Demeke, T. and R.P. Adams. 1992. The effects of plant polysaccharides and buffer additives on PCR. BioTechniques 12: 332 334.

4. D'Aquila, R.T., L.J. Bechtel, J.A. Videler, J.J. Eron, P. Gorczyca, and J.C. Kaplan. 1991. Maximizing sensitivity and specificity of PCR by preamplification heating. Nucleic Acids Res. 19: 3749.

5. Mullis, K. B. 1991. The polymerase chain reaction in an anemic mode: How to avoid cold oligodeoxyribonuclear fusion. PCR Methods Applic. 1: 1-4.

6. Oshima, R.G. 1992. Single-stranded DNA binding protein facilitates amplification of genomic sequences by PCR. BioTechniques 13: 188.

7. Sarkar, G., S. Kapelner, and S.S. Sommer. 1990. Formamide can dramatically improve the specificity of PCR. Nucleic Acids Res. 18: 7465.

8. Bouché, J.P. 1981. The effect of spermidine on endonuclease inhibition by agarose contaminants. Anal. Biochem. 115: $42-45$.

9. Tobor, C.W. and H. Tobor. 1976. 1,4-Diaminiobutane (putrescine), spermidine and spermine. Annu. Rev. Biochem. 53: 749-790.

10. Fisher, P.A. and D. Korn. 1979. Enzymological characterization of KB cell DNA polymerase- $\alpha$. II. Specificity of the protein-nucleic acid interaction. J. Biol. Chem. 254: 11033-11039.

11. Pommier, Y., D. Kerrigan, and K. Kohn. 1989. Topological complexes between DNA and topoisomerase II and effects of polyamines. Biochemistry 28: 995-1002.

12. Blanchard, M.M., P. Taillon-Miller, P. Nowotny, and V. Nowotny. 1993. PCR buffer optimization with uniform temperature regimen to facilitate automation. $P C R$ Methods Applic. 2: 234-240.

13. Galau, G.A., H.W. Bass, and D.W. Hughes. 1988. Restriction fragment length polymorphisms in diploid and allotetraploid Gossypium: Assigning the late embryogenesis-abundant (Lea) alloalleles in G. hirsutum. Mol. Gen. Genet. 211: 305-314.

14. Maniatis, T., E.F. Fritsch, and J. Sambrook. 1982. Molecular cloning: A laboratory manual. Cold Spring Harbor Laboratory, Cold Spring Harbor, New York.

15. Wilkins, T.A. 1993. Vacuolar $\mathrm{H}^{+}$-ATPase 69-kilodalton catalytic subunit cDNA from developing cotton (Gossypium hirsutum) ovules. Plant Physiol. 102: 679-680.

Received August 2, 1993; accepted in revised form October 18, 1993. 


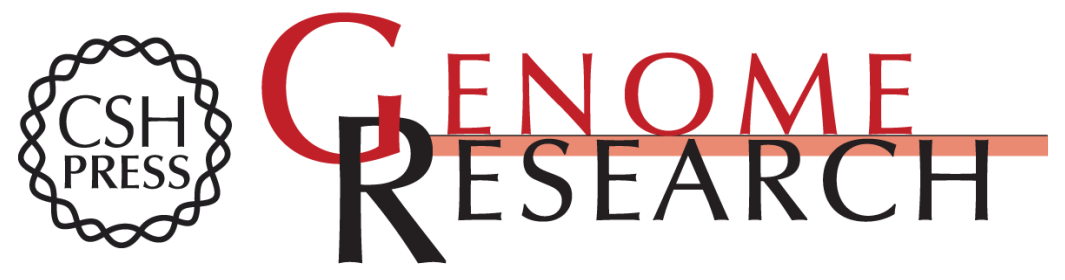

\section{Spermidine facilitates PCR amplification of target DNA.}

C Y Wan and T A Wilkins

Genome Res. 1993 3: 208-210

References This article cites 14 articles, 2 of which can be accessed free at:

http://genome.cshlp.org/content/3/3/208.full.html\#ref-list-1

\section{License}

Email Alerting Receive free email alerts when new articles cite this article - sign up in the box at the Service top right corner of the article or click here.

\section{Affordable, Accurate Sequencing.}

To subscribe to Genome Research go to: https://genome.cshlp.org/subscriptions 